\begin{tabular}{c|c|c}
\hline \hline & AQUATIC MICROBIAL ECOLOGY & Aquat Microb Ecol \\
Vol. 32: 73-84, 2003 & Published May 12 \\
\hline
\end{tabular}

\title{
Kill and eat your predator: a winning strategy of the planktonic flagellate Prymnesium parvum
}

\author{
Urban Tillmann*
}

Alfred Wegener Institute, Am Handelshafen 12, 27570 Bremerhaven, Germany

\begin{abstract}
Interactions between the toxic and mixotrophic haptophyte Prymnesium parvum and the heterotrophic dinoflagellate Oxyrrhis marina were investigated in P-limited semi-continuous cultures and nutrient-replete batch culture experiments. When exposed to $100 \times 10^{3} \mathrm{cells} \mathrm{ml}^{-1}$ of Plimited $P$. parvum, starved $O$. marina initially ingested the algae, but ingestion was low $(0.07$ cells grazer $^{-1} \mathrm{~h}^{-1}$ ) compared to the $O$. marina ingestion rate when the Cryptophyte Rhodomonas sp. was offered as food (2.75 cells grazer $\left.{ }^{-1} \mathrm{~h}^{-1}\right)$. Microscopic observations showed that low ingestion is due to toxic effects of $P$. parvum on the dinoflagellate. Cells of $O$. marina lost their normal cell shape and became rounded, hyaline and finally lysed. Rounded and partly lysed O. marina cells were rapidly attacked by several $P$. parvum cells, which formed larger aggregates around the remains of the $O$. marina cells. This was accompanied by phagotrophic ingestion of particulate material originating from disintegrating $O$. marina. Cell-free culture medium lysed $O$. marina cells, although to a lower degree compared to the effect of algal suspensions. O. marina mortality was not only reduced by diluting P. parvum, but also by increasing the dinoflagellate concentration. This clearly indicates that the toxin is removed from the system by its action, presumably by binding to the membrane. Under conditions where toxic effects were not apparent (nutrient-replete batch cultures, low cell concentrations, dim light), P. parvum, after an initial lag period, was rapidly ingested and sustained growth of $O$. marina at rates comparable to those estimated for Rhodomonas sp. Toxicity of $P$. parvum is thus a key factor in determining the interaction with protozoan grazers. If toxicity is low, $P$. parvum is a suitable prey for $O$. marina. At high toxicity levels, however, $O$. marina is rapidly killed and ingested by P. parvum, thus reversing the normal direction of grazing interactions between protozoa and algae.
\end{abstract}

KEY WORDS: Prymnesium parvum • Oxyrrhis marina · Toxic algae · Interaction · Grazing · Mixotrophy $\cdot$ Chemical defence

\section{INTRODUCTION}

The haptophycean species Prymnesium parvum and $P$. patelliferum are well known to form dense blooms in brackish and coastal marine waters around the world (reviewed by Moestrup 1994, Edvardsen \& Paasche 1998). There is increasing genetic evidence that $P$. parvum and P. patelliferum, despite their small differences in the fine-structural details of body scales (Green et al. 1982), should be considered as 1 species (Larsen \& Medlin 1997, Larsen 1999), and I do so in the following discussion. Blooms of Prymnesium parvum have been associated with massive fish mortalities (e.g. Reich \& Aschner 1947, Holdway et al. 1978,
Kaartvedt et al. 1991) and may cause severe damage to the whole ecosystem (Valkanov 1964, Petrova 1966). P. parvum produces a set of highly potent toxins commonly called prymnesin (Shilo 1981, Igarashi et al. 1996) which may be excreted into the surrounding waters (Shilo \& Aschner 1953). The toxins have a broad spectrum of different biological effects. In addition to ichthyotoxic (Ulitzur \& Shilo 1966) and pharmacological activities (Meldahl \& Fonnum 1993, 1995) Prymnesium toxins exert lytic effects on various cell types, such as erythrocytes (Yariv \& Hestrin 1961), bacteria (Ulitzur \& Shilo 1970), and a number of nucleated cells (Shilo \& Rosenberg 1960, Dafni \& Giberman 1972). Purified Prymnesium toxin preparation (prymnesin) 
has been shown to be one of the most active lysins described (Ulitzur \& Shilo 1970, Igarashi et al. 1998).

Acute toxicity towards 'standard toxicity test' systems, including blood cells, Artemia spp., cytological material or fish has been investigated in most studies. However, there is only limited information on interactions of Prymnesium spp. and co-occurring zooplankton grazers, although reduced or inhibited grazing is generally believed to be an important factor in harmful bloom dynamics (Fiedler 1982, Smayda 1997). Valkanov (1964) demonstrated qualitatively that copepod species showed no sign of mortality or exhaustion upon exposure to P. parvum and this obviously low sensitivity of copepods towards Prymnesium has been validated (Nejstgaard et al. 1995, Nejstgaard \& Solberg 1996). A wide range of protozoan species, however, are severely affected upon exposure to P. parvum (Valkanov 1964). Likewise, laboratory experiments of Johannsson (2000) showed that increasing abundances of $P$. parvum increased mortality of the ciliate Euplotes affinis.

Toxin production is not the only distinctive characteristic of Prymnesium. Despite the intense research on Prymnesium in the last half century, it was only recently that phagotrophy of this genus was convincingly described (Nygaard \& Tobiesen 1993, Tillmann 1998, Legrand et al. 2001). It was shown that Prymnesium is able to incorporate different sized particles (sometimes even larger than itself) including heterotrophic protozoans like amoeba or the heterotrophic dinoflagellate Oxyrrhis marina (Tillmann 1998). Based on qualitative observations, Tillmann (1998) speculated that Prymnesium toxin may be used to kill potential prey organisms prior to ingestion. However, quantitative data on that topic are still missing.

The aim of the present paper was to quantitatively analyse the interactions between Prymnesium parvum and a protozoan grazer. The heterotrophic dinoflagellate Oxyrrhis marina, a species that co-occurs with Prymnesium in a brackish pond in northern Germany (own observation), was chosen as the grazer.

\section{MATERIALS AND METHODS}

The heterotrophic dinoflagellate Oxyrrhis marina (Göttingen culture collection, Strain B21.89) was gradually adapted to a salinity of $10 \% 2$ mo before the experiment started. Stock cultures held in $100 \mathrm{ml}$ flasks were regularly fed Dunaliella sp. or Rhodomonas sp. pre-cultured with $10 \%$ f/10 medium (0.1 strength f-medium, Guillard \& Ryther 1962). Cultures of $O$. marina used in the experiments were grown at $15^{\circ} \mathrm{C}$ to high densities until they became almost deprived of food. In experiments where it was desirable to keep the volume added to Prymnesium parvum cultures as low as possible, O. marina cultures were gently concentrated by gravity filtration (Nuclepore filters, pore size $1 \mu \mathrm{m}$ ).

Semi-continuous culture experiments (P-limited). Algal culture conditions: Prymnesium parvum (Kalmar University Culture Collection, strain KAC39) was cultivated non-axenically in f/10-medium prepared from GF/C-filtered and pasteurised coastal seawater (Baltic Sea). The original salinity of the seawater, $7 \%$, was adjusted to $10 \%$ by adding $\mathrm{NaCl}$.

Triplicate P-limited semi-continuous cultures were established from batch cultures as described in detail by Skovgaard et al. (2003). The culture bottles (3 l Pyrex bottles) were gently aerated and kept in a controlled environment room at $15^{\circ} \mathrm{C}$ under a light:dark cycle of 16:8 h. Irradiance, measured inside the culture bottles with a QSL-100 Quantum Scalar Irradiance Meter (Biospherical Instruments), was 90 to $100 \mu \mathrm{E} \mathrm{\textrm {m } ^ { - 2 }}$ $\mathrm{s}^{-1}$. Cell concentrations were monitored at least every second day by counting $>400$ cells in Lugol's fixed samples in a Sedgewick Rafter counting cell (Graticules). The cultures were diluted $15 \%$ daily by removing $300 \mathrm{ml}$ of culture volume and replenishing it with modified f/10-medium where $\mathrm{PO}_{4}{ }^{3-}$ was the limiting nutrient at an $\mathrm{N}: \mathrm{P}$ ratio of $80: 1 \quad\left(14.5 \mu \mathrm{M} \mathrm{NO}{ }_{3}{ }^{-}\right.$and $0.18 \mu \mathrm{M} \mathrm{PO}_{4}{ }^{3-}$ ). Trace metals and vitamins were always added in amounts corresponding to full strength f/10-medium. Daily dilution was performed at

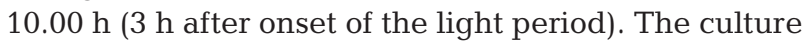
volume withdrawn was then used for subsequent experiments. These experiments described below were carried out in a time period of $10 \mathrm{~d}$.

Grazing of Oxyrrhis marina: An experiment was conducted to estimate grazing of Oxyrrhis marina on P-limited (-P) Prymnesium parvum. Five ml of a mixture of each $P$. parvum -P culture (final concentration: $100 \times 10^{3} \mathrm{ml}^{-1}$ ) or Rhodomonas sp. (final concentration: $95 \times 10^{3} \mathrm{ml}^{-1}$ ) and $O$. marina culture (final concentration: $400 \mathrm{ml}^{-1}$ ) were prepared in $20 \mathrm{ml}$ glass vials and incubated at $15^{\circ} \mathrm{C}$ and $30 \mu \mathrm{E} \mathrm{m}^{-2} \mathrm{~s}^{-1}$. O. marina used in that experiment were feed with Rhodomonas sp. and then starved for $6 \mathrm{~d}$ to ensure that only low numbers of algae in food vacuoles were present. A fixed incubation time of $1 \mathrm{~h}$ was chosen to compare initial food uptake of the 2 different algal species. At the beginning and after $1 \mathrm{~h}$ incubation, $1 \mathrm{ml}$ subsamples were pipetted into $2 \mathrm{ml}$ Utermöhl chambers and fixed with $1 \%$ glutaraldehyde. After settlement, cells were inspected under an inverted microscope using fluorescence light (Zeiss filter set 14). Counts of the number of ingested algal cells, which were easily recognisable by their red ( $P$. parvum) or orange (Rhodomonas sp.) fluorescence, of at least 200 individuals of $O$. marina allowed for the determination of food uptake rate (algae grazer ${ }^{-1} \mathrm{~h}^{-1}$ ). 
Short-term negative effects: To analyse short-term negative effects of Prymnesium parvum -P on Oxyrrhis marina, $10 \mathrm{ml}$ of a mixture of each $P$. parvum $-\mathrm{P}$ culture (final concentration: $100 \times 10^{3} \mathrm{ml}^{-1}$ ) and O. marina culture (final concentration: $700 \mathrm{ml}^{-1}$ ) were prepared in $20 \mathrm{ml}$ glass vials and incubated at $15^{\circ} \mathrm{C}$ and $30 \mu \mathrm{E} \mathrm{m} \mathrm{m}^{-2} \mathrm{~s}^{-1}$. Filtered seawater instead of algal suspension served as a control. After 0, 0.5, 1, 2, 4, 6 and $10 \mathrm{~h}, 1 \mathrm{ml}$ subsamples were pipetted into $2 \mathrm{ml}$ Utermöhl chambers and fixed with Lugol's iodine. Preliminary microscopic examinations had shown that after exposure to $P$. parvum cultures, O. marina lost its motility, became rounded, hyaline and finally lysed. Rounded and partly lysed O. marina cells were rapidly attacked by several $P$. parvum cells forming larger 'aggregates' around the remains of the $O$. marina cells. To quantify the lytic effects of $P$. parvum, O. marina was counted in the whole chamber, and a cell was scored only if the normal cell shape was still visible. Results are expressed as percentage of 'intact cells' compared to the seawater control. In addition, one experiment was performed to compare the short-term effects on immobilisation and lysis of $O$. marina. Aliquots of $0.5 \mathrm{ml}$ of a concentrated $O$. marina culture (final concentration: $1200 \mathrm{ml}^{-1}$ ) were mixed with $10 \mathrm{ml}$ of P. parvum -P (final concentration: $95 \times 10^{3} \mathrm{ml}^{-1}$ ) or with $10 \mathrm{ml}$ of seawater as control. After a defined exposure time $(0,0.5,1,2,4,6 \mathrm{~h})$ at ambient light and room temperature, subsamples were taken to estimate immobilisation and lysis. Immobilisation was estimated by counting the number of moving $O$. marina cells using a slightly modified droplet live-counting procedure as described by Tillmann \& John (2002). Briefly, $200 \mu \mathrm{l}$ of cell suspension were separated into 50 to 60 small droplets in a Petri dish and the number of moving $O$. marina cells was counted under a stereo microscope. Cell lysis was estimated by counting numbers of intact $O$. marina cells in $0.5 \mathrm{ml}$ fixed with Lugol's iodine. To follow the time course of the formation of 'round cells' and aggregates (see Figs. 1 \& 2), the counting protocol used in this experiment included the enumeration of round cells and of aggregates with triplicate samples at $0,0.5,1$ and $2 \mathrm{~h}$ and single samples at 4 and $6 \mathrm{~h}$.

Dilution series: A concentration/response curve was recorded in order to estimate the cell concentration causing $50 \%$ effect $\left(\mathrm{EC}_{50}\right)$. In triplicate, $5 \mathrm{ml}$ of a mixture of Oxyrrhis marina (final concentration: $800 \mathrm{ml}^{-1}$ ) and different amounts of Prymnesium parvum -P culture were prepared in $20 \mathrm{ml}$ glass vials. Six different final $P$. parvum cell concentrations $(75,56,38,19,8$ and $0 \times 10^{3} \mathrm{ml}^{-1}$ ) were prepared by appropriate dilution with fresh medium. Just after mixing and after $6 \mathrm{~h}$ of incubation at $15^{\circ} \mathrm{C}$ and $30 \mu \mathrm{E} \mathrm{m}^{-2} \mathrm{~s}^{-1}, 1 \mathrm{ml}$ subsamples were fixed with Lugol's iodine and counted as described above. Mortality, defined as 100 minus the percentage of intact cells compared to the seawater control, was transformed to probits (Hewlett \& Placklet 1979). $\mathrm{EC}_{50}$ values, defined as the number of $P$. parvum needed to induce $50 \%$ mortality after 6 h of incubation, were calculated by linear regression analysis of probits against log-transformed $P$. parvum concentrations.

Effect of filtrate: In one experiment, the effect of cellfree culture filtrate was tested. In triplicate, $5 \mathrm{ml}$ of a mixture of Oxyrrhis marina (final concentration: $800 \mathrm{ml}^{-1}$ ) and either Prymnesium parvum -P culture (final concentration: $97 \times 10^{3} \mathrm{ml}^{-1}$ ) or cell-free filtrate (prepared by gentle syringe filtration through a Whatman GFF filter and added at the same amount as the algal suspension), were prepared in $20 \mathrm{ml}$ glass vials. Filtered seawater served as a control. Vials were incubated at $15^{\circ} \mathrm{C}$ and $30 \mu \mathrm{E} \mathrm{m} \mathrm{m}^{-2} \mathrm{~s}^{-1}$. At time 0,6 and $24 \mathrm{~h}$ subsamples were taken to estimate immobilisation and lysis as described previously.
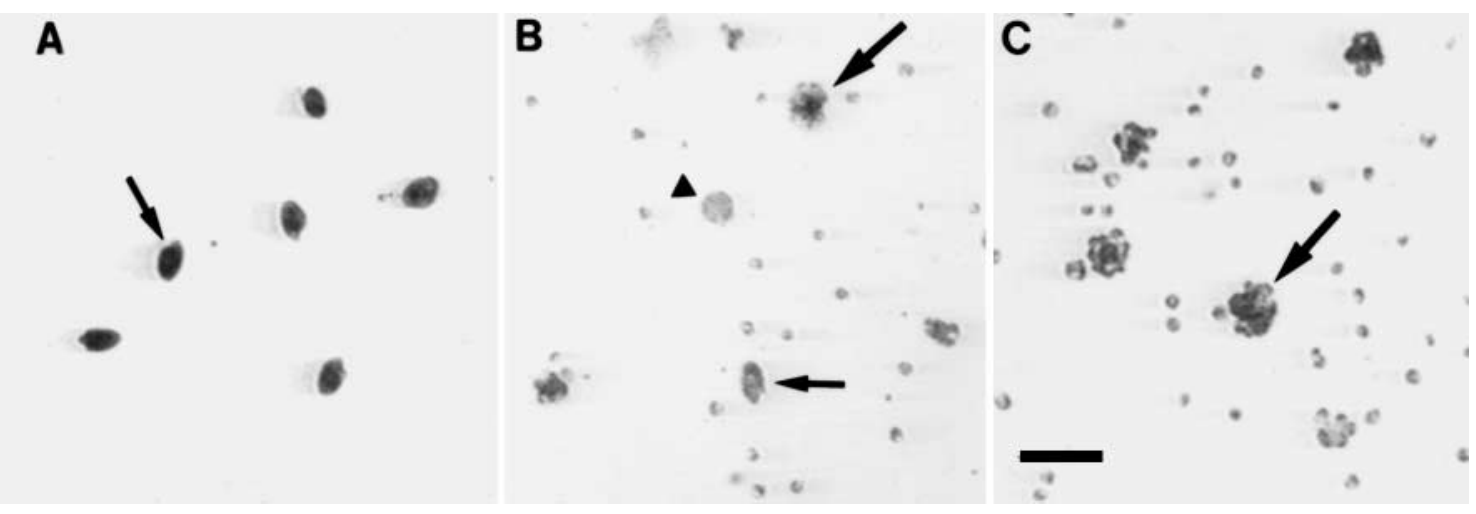

Fig. 1. Video prints of Lugol's fixed samples from the short-term experiments. (A) In control samples incubated with fresh medium, all cells of Oxyrrhis marina (thin arrow) exhibited the normal elongated cell shape. (B, C) In samples incubated with Prymnesium parvum -P, 'intact cells' of $O$. marina (thin arrow) as well as 'round cells' (arrowhead) and 'aggregates' (bold arrows) consisting of $P$. parvum around the remains of $O$. marina can be seen. Scale bar $=40 \mu \mathrm{m}$ 
Addition of different Oxyrrhis marina concentrations: One experiment was carried out to study the effects of adding different amounts of Oxyrrhis marina. A series of equivalent Prymnesium parvum -P inoculum (final concentration: $20 \times 10^{3} \mathrm{ml}^{-1}$ ) or seawater as a control was exposed to 8 different $O$. marina densities ranging from 220 to 81000 cells $\mathrm{ml}^{-1}$. Different $O$. marina concentrations were established by appropriate dilution of a concentrated $O$. marina culture.

A

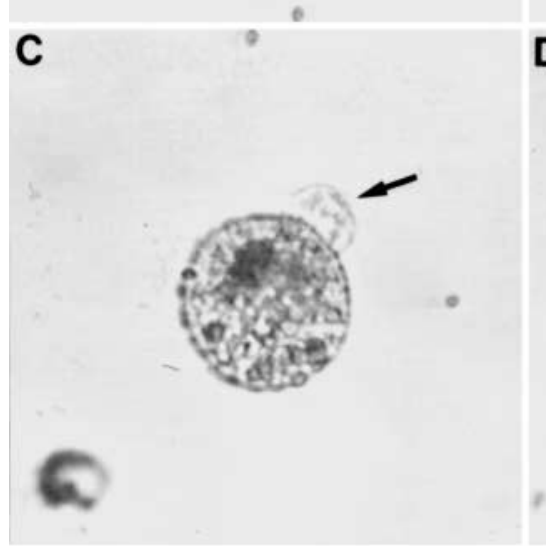

E

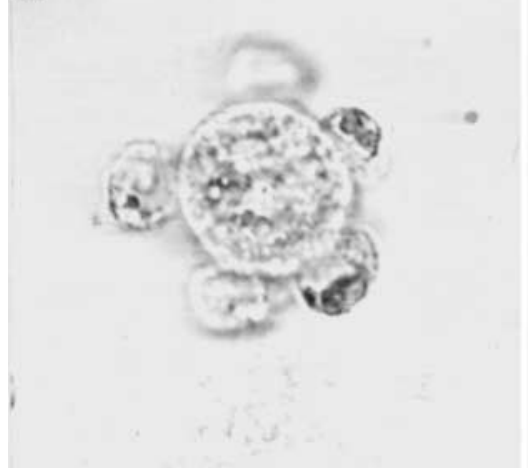

Fig. 2. Video prints of Lugol's fixed samples from the short-term experiments. (A) Oxyrrhis marina with its normal shell shape. (B) O. marina completely rounded off. (C, D, E) A varying number of Prymnesium parvum cells (arrows) have settled on the surface of $O$. marina round cells. (F) 'Feeding aggregate' with $O$. marina almost disintegrated. Note that the sequence of prints is not a true time course. Scale bar $=10 \mu \mathrm{m}$
Three replicates and 1 control were set up for each dinoflagellate concentration. After $6 \mathrm{~h}$ of incubation at $15^{\circ} \mathrm{C}$ and $30 \mu \mathrm{E} \mathrm{m}{ }^{-2} \mathrm{~s}^{-1}$, varying amounts were fixed with Lugol's iodine in order to obtain about $700 \mathrm{O}$. marina cells to count in the entire sample volume of the control sample. As described before, O. marina cells with a normal cell shape were counted. Percentage mortality was calculated by comparing cell numbers of samples with the seawater control.

Successive addition of Oxyrrhis marina: Six identical mixtures of $5 \mathrm{ml}$ of Prymnesium parvum -P or seawater as a control and $50 \mu \mathrm{l}$ of a concentrated Oxyrrhis marina were prepared in $20 \mathrm{ml}$ glass vials, resulting in a final concentrations of $46 \times 10^{3} \mathrm{ml}^{-1}$ and $900 \mathrm{ml}^{-1}$ for $P$. parvum and $O$. marina, respectively. After $1 \mathrm{~h}$ incubation at $15^{\circ} \mathrm{C}$ and $30 \mu \mathrm{E}$ $\mathrm{m}^{-2} \mathrm{~s}^{-1}, 1 \mathrm{ml}$ subsamples were taken. To the remaining $\sim 4 \mathrm{ml}$ sample, $40 \mu \mathrm{l}$ of a concentrated $O$. marina suspension were added (equivalent to 900 O. marina $\mathrm{ml}^{-1}$ ). The whole procedure $(1 \mathrm{~h}$ incubation, $1 \mathrm{ml}$ subsamples, addition of $O$. marina with ca. $900 \mathrm{ml}^{-1}$ ) was repeated 5 times. All subsamples were fixed with Lugol's iodine and analysed as described above.

Batch culture experiment. To test whether 'low toxic' Prymnesium parvum supports growth of Oxyrrhis marina, the following experiment was carried out. A batch culture of $P$. parvum grown in filtered North Sea seawater diluted with distilled water to a salinity of $10 \%$ and enriched with $f / 10$ nutrient solution was incubated at $15^{\circ} \mathrm{C}$ and $30 \mu \mathrm{E} \mathrm{m} \mathrm{m}^{-2} \mathrm{~s}^{-1}$. Cell growth was monitored taking daily samples for cell counts. When the culture reached a density of about $50 \times 10^{3} \mathrm{ml}^{-1}$, a series of equivalent $O$. marina inoculum (final concentration: $500 \mathrm{ml}^{-1}$ ) was exposed to 6 different $P$. parvum densities ranging from 0 to $42 \times 10^{3}$ cells ml $^{-1}$. Different $P$. parvum concentrations were established by appropriate dilution of the $P$. parvum batch culture. A total volume of $15 \mathrm{ml}$ of each mixture was prepared in $20 \mathrm{ml}$ glass-vials. Vials containing the same concentrations of phytoplankton only served as control. At time 0, initial samples were taken for determination of cell concentrations. Subsequently, the volume of each vial was split into 3 wells of a multiwell plate (Nunc) and incubated at $15^{\circ} \mathrm{C}$ under dim light $\left(2 \mu \mathrm{E} \mathrm{m}{ }^{-2}\right.$ 
$\mathrm{s}^{-1}$ ). The same experiment was set up synchronously with Rhodomonas sp. as a non-toxic control species. Although Rhodomonas sp. and $P$. parvum differed slightly in size (microscopical size measurements using Lugol fixed samples; length $\times$ width $(\mathrm{n}=50)$ : $11.9 \pm 0.6$ $\times 7.0 \pm 0.5 \mu \mathrm{m}_{i} 9.2 \pm 0.9 \times 5.5 \pm 0.7 \mu \mathrm{m}$, respectively), the same algal concentrations were used as outlined above. After 2, 6 and $11 \mathrm{~d}$ incubation, a $1 \mathrm{ml}$ subsample was taken from each well and fixed with Lugol's iodine. Cell concentrations of $O$. marina and P. parvum (or Rhodomonas sp.) were determined with an inverted microscope. Growth and ingestion for the periods 0 to 2 and 0 to $6 \mathrm{~d}$ were calculated from the initial cell concentrations and the cell concentrations of the accordant sampling day using the equations of Frost (1972) and Heinbokel (1978).

\section{RESULTS}

\section{Semi-continuous culture experiments}

Prymnesium parvum cell concentrations

Before the experiments started, cell numbers of Prymnesium parvum in the semi-continuous cultures slightly decreased from 140 to $120 \times 10^{3} \mathrm{ml}^{-1}$. After the first $5 \mathrm{~d}$ of experiments, where concentrations were around $100 \times 10^{3} \mathrm{ml}^{-1}$, cell concentrations steadily decreased down to $45 \times 10^{3} \mathrm{ml}^{-1}$ by the end of the experiment.

\section{Grazing of Oxyrrhis marina on Prymnesium parvum}

Starved Oxyrrhis marina initially ingested Prymnesium parvum $-\mathrm{P}$, but only at a very low rate $(0.07 \pm 0.01$ algal cells grazer ${ }^{-1} \mathrm{~h}^{-1}$ ). When fed with the non-toxic control species Rhodomonas sp., the ingestion rate of O. marina was as high as $2.75 \pm 0.02$ algal cells grazer $^{-1} \mathrm{~h}^{-1}$.

Short-term effects of Prymnesium parvum towards Oxyrrhis marina

Prymnesium parvum caused harmful, microscopically visible effects on the heterotrophic dinoflagellate Oxyrrhis marina. Cells of the dinoflagellate lost their normal cell shape and became rounded, hyaline and finally lysed (Figs. $1 \& 2$ ). Rounded and partly lysed $O$. marina cells were rapidly attacked by several $P$. parvum cells forming larger aggregates around the remains of the $O$. marina cells (Figs. 1 \& 2). Live microscopy clearly showed the formation of posteriorly located pseudopodia and subsequent ingestion of particulate material originating from disintegrating O. marina by Prymnesium parvum as described in detail by Tillmann (1998). As can be seen from Figs. 1 \& 2, a clear differentiation between $O$. marina cells with their typical cell shape and rounded or partly lysed individuals in Lugol's fixed samples was possible. Lytic effects were analysed in a time course experiment. The number of intact $O$. marina cells, calculated as a percentage of initial values, remained constant with time for the seawater control. Cell lysis was evident, however, for the algal treatments. The number of intact cells sharply decreased during the first $2 \mathrm{~h}$ and than slowly reached a constant level of about $10 \%$ of the initial values (results not shown). In a similar experiment subsequently performed, the immobilising and lytic effect of toxins was simultaneously analysed (Fig. 3). Immobilisation of O. marina and cell lysis showed almost the same time course, indicating a close coupling between these 2 processes. The detailed enumeration of intact cells, round cells and of 'feeding aggregates' (consisting of $P$. parvum cells phagocytosing partly lysed O. marina remains) is shown in Fig. 4. In the control, numbers of intact $O$. marina cells stayed quite constant over time. When incubated with $P$. parvum, number of intact $O$. marina cells decreased with time. The number of round cells peaked after 30 min of incubation and subsequently declined again. In contrast, the number of feeding aggregates steadily increased during the first $2 \mathrm{~h}$ of incubation. The sum of intact cells, round cells and feeding aggregates slightly decreased with time indicating some total disintegration of O. marina. However, the data show that killed

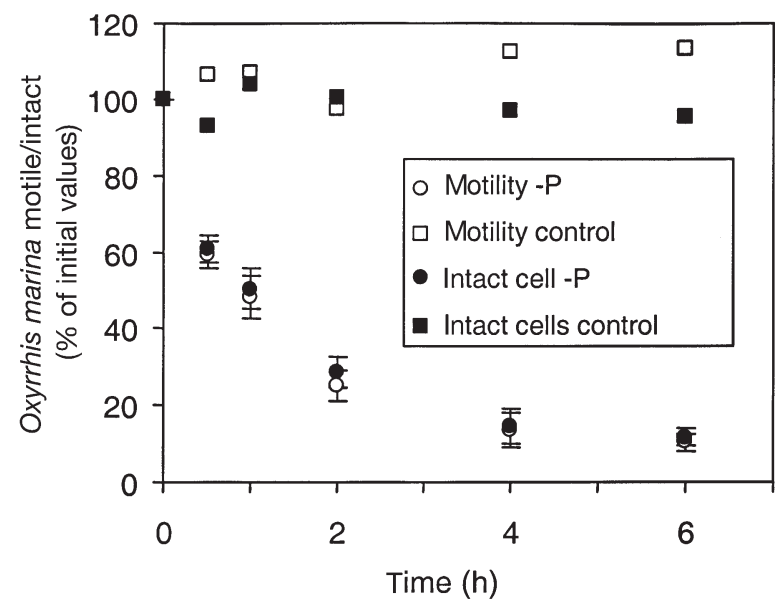

Fig. 3. Motile or intact Oxyrrhis marina (\% of initial values) versus time when incubated with Prymnesium parvum -P (final concentration: $95 \times 10^{3} \mathrm{ml}^{-1}$ ). Data points for experimental flasks represent mean values $(n=3)$ with error bars $( \pm 1 \mathrm{SD})$; control $(\mathrm{n}=1)$ 


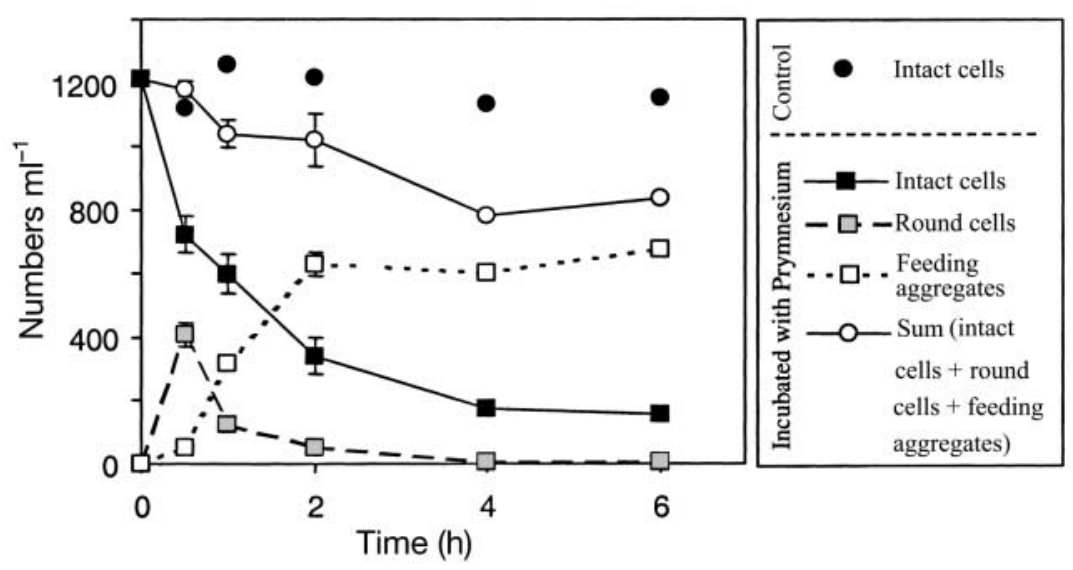

Fig. 4. Concentration of Oxyrrhis marina 'intact cells', 'round cells' and 'aggregates' and the sum of all 3 versus time, when incubated with Prymnesium parvum -P (final concentration: $95 \times 10^{3} \mathrm{ml}^{-1}$ ). For a definition of the various cell types see Figs. $1 \& 2$. Data points for time 0, 0.5, 1 and $2 \mathrm{~h}$ represent mean values $(n=3)$ with error bars $( \pm 1 S D) ; 4$ and $6 h(n=1)$

O. marina cells predominantly ended as feeding aggregates.

The cell concentrations causing $50 \%$ cell lysis were determined by recording a dilution/response curve (Fig. 5) which showed a sigmoid relation between percent of Oxyrrhis marina mortality and Prymnesium parvum cell concentration. The $\mathrm{EC}_{50}$ value, defined as the amount of algae needed to induce $50 \%$ mortality after $6 \mathrm{~h}$ of incubation, was $16 \times 10^{3}$ cells ml $\mathrm{m}^{-1}$.

\section{Effects of culture filtrate}

A negative effect on Oxyrrhis marina also was obvious when testing Prymnesium parvum cell-free culture filtrate (Fig. 6). The immobilisation effect of filtrate, however, was lower compared to the effect of algal

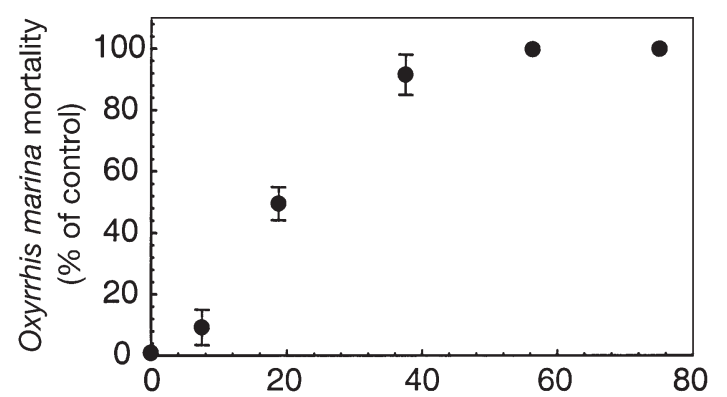

Prymnesium parvum concentration $\left(\times 10^{3} \mathrm{ml}^{-1}\right)$

Fig. 5. Dilution/response curve for Oxyrrhis marina incubated with Prymnesium parvum -P. O. marina mortality (\% of control) as a function of $P$. parvum cell concentration. Data points represent mean values $(n=3)$ with error bars $( \pm 1 \mathrm{SD})$ suspensions (same cell concentration as used for the filtrate). The difference between cell free filtrate and algal suspension was most obvious for the lytic effect; after $6 \mathrm{~h}$ of incubation, the number of intact cells was not significantly different from the seawater control. After $24 \mathrm{~h}$, the number of intact cells was reduced in only 2 of 3 parallel preparations causing the large SD in Fig. 6B.

\section{Changing Oxyrrhis marina concentration}

The percentage of Oxyrrhis marina mortality is not only reduced by diluting the Prymnesium parvum culture (see Fig. 5), but also by increasing the dinoflagellate concentration (Fig. 7). When exposed to 20 $\times 10^{3} \mathrm{P}$. parvum $\mathrm{ml}^{-1}$, mortality was almost $100 \%$ for $O$. marina concentrations $<1000 \mathrm{ml}^{-1}$. With increasing $O$. marina concentration, mortality declined to about $25 \%$ at a concentration of $8100 \mathrm{O}$. marina $\mathrm{ml}^{-1}$. The effect of a reduced percentage mortality upon elevated target concentration is also apparent when $O$.
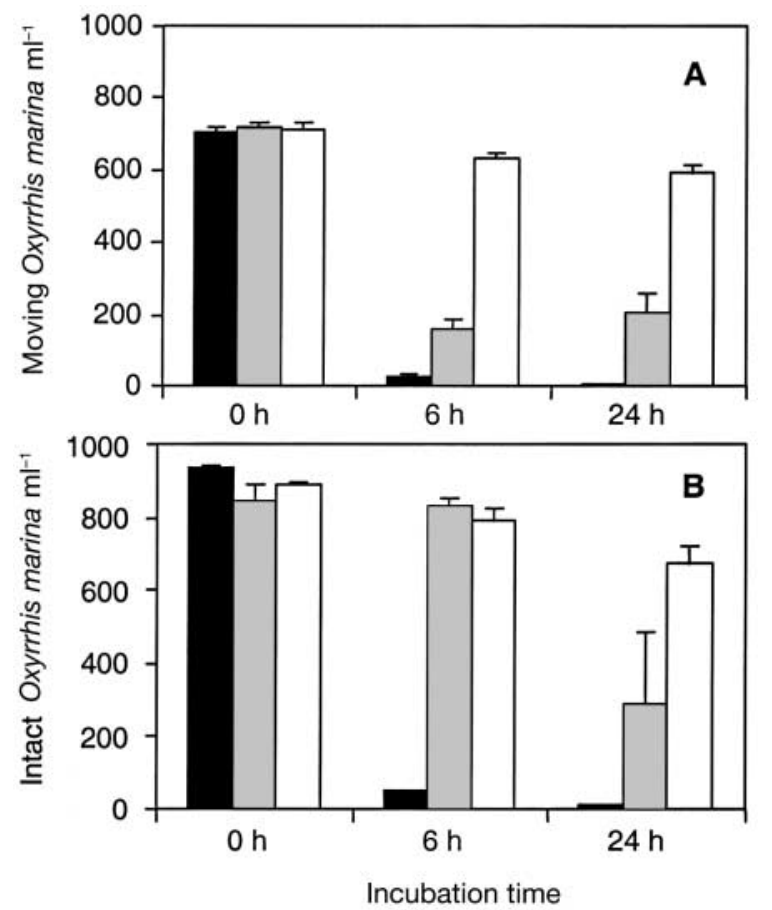

Fig. 6. Number per $\mathrm{ml}$ of (A) motile or (B) intact Oxyrrhis marina after 0, 6 and $24 \mathrm{~h}$ exposure to whole cells (black bars) or to culture filtrate (grey bars) of Prymnesium parvum -P (final concentration: $97 \times 10^{3} \mathrm{ml}^{-1}$ ) or to fresh medium (control, white bars). Results are expressed as triplicate mean $\pm 1 \mathrm{SD}$ 


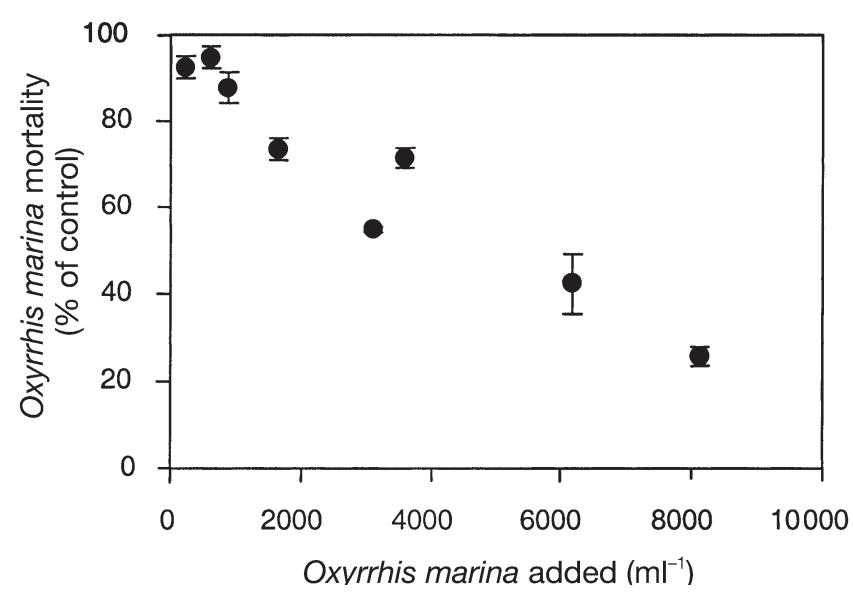

Fig. 7. Oxyrrhis marina mortality (\% of control) as a function of initial O. marina concentration. Different $O$. marina concentrations were exposed to Prymnesium parvum -P (final concentration: $20 \times 10^{3} \mathrm{ml}^{-1}$ ) for $6 \mathrm{~h}$. Data points represent mean values $(n=3)$ with error bars $( \pm 1 \mathrm{SD})$

marina mortality is recorded upon successive additions to the same algal suspension (Fig. 8). For the first 3 additions of $O$. marina, a mortality close to $100 \%$ was recorded. Upon further additions of $O$. marina, however, mortality declined, reaching 0 after the 5 th addition.

\section{Batch culture experiment}

Under the environmental conditions and cell concentrations tested, Prymnesium parvum caused toxic effects on Oxyrrhis marina. The following experiment tested whether $O$. marina is able to graze and grow on $P$. parvum under conditions of 'low toxicity' of the algae. To achieve these conditions, $P$. parvum grown under nutrient-replete conditions was offered as food in a range of low cell concentrations at dim light (assuming that photosynthesis is a prerequisite of toxin production). Ingestion and growth of $O$. marina fed with $P$. parvum was compared to results when Rhodomonas sp. was offered as food. When estimated after $2 \mathrm{~d}$ incubation, ingestion of Rhodomonas sp. was high and almost linearly dependant on the initial algal concentration, reaching 14 cells grazer ${ }^{-1} \mathrm{~d}^{-1}$ at the highest Rhodomonas sp. concentration. In contrast, initial ingestion of $P$. parvum calculated for the 0 to $2 \mathrm{~d}$ period was comparably high only at the 2 lowest algal concentrations and dropped to almost 0 at the highest P. parvum concentration (Fig. 9A). Correspondingly, growth rate of Oxyrrhis marina increased with increasing Rhodomonas sp. concentrations but remained low with Prymnesium parvum as food. Furthermore, a negative growth rate, i.e. cell death, was observed at the highest P. parvum concentration (Fig. 9B). However,

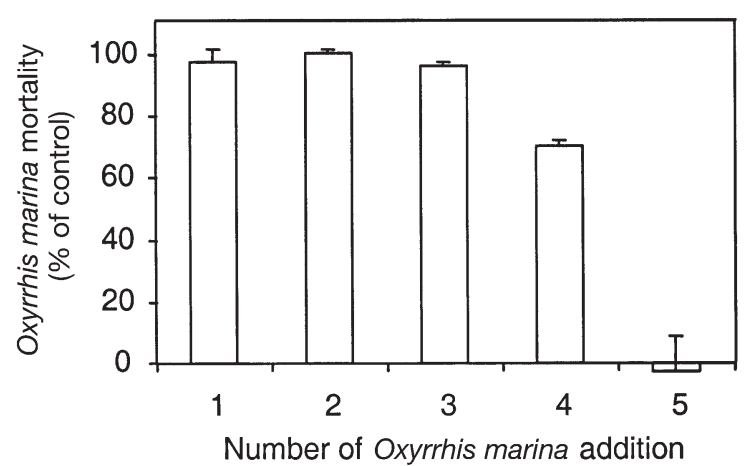

Fig. 8. Effect of successive addition of Oxyrrhis marina to Prymnesium parvum -P (final concentration: $46 \times 10^{3} \mathrm{ml}^{-1}$ ). P. parvum (or fresh medium: control) was spiked with O. marina, incubated for $1 \mathrm{~h}$ and a subsample was withdrawn for the determination of numbers of intact $O$. marina (Addition 1). Subsequently, the same sample was spiked again with new $O$. marina and processed as described before (Addition 2). This procedure was repeated 5 times. The figure shows mortality of $O$. marina (\% of control) after each addition. Data points represent mean values $(n=6)$ with error bars $( \pm 1 \mathrm{SD})$
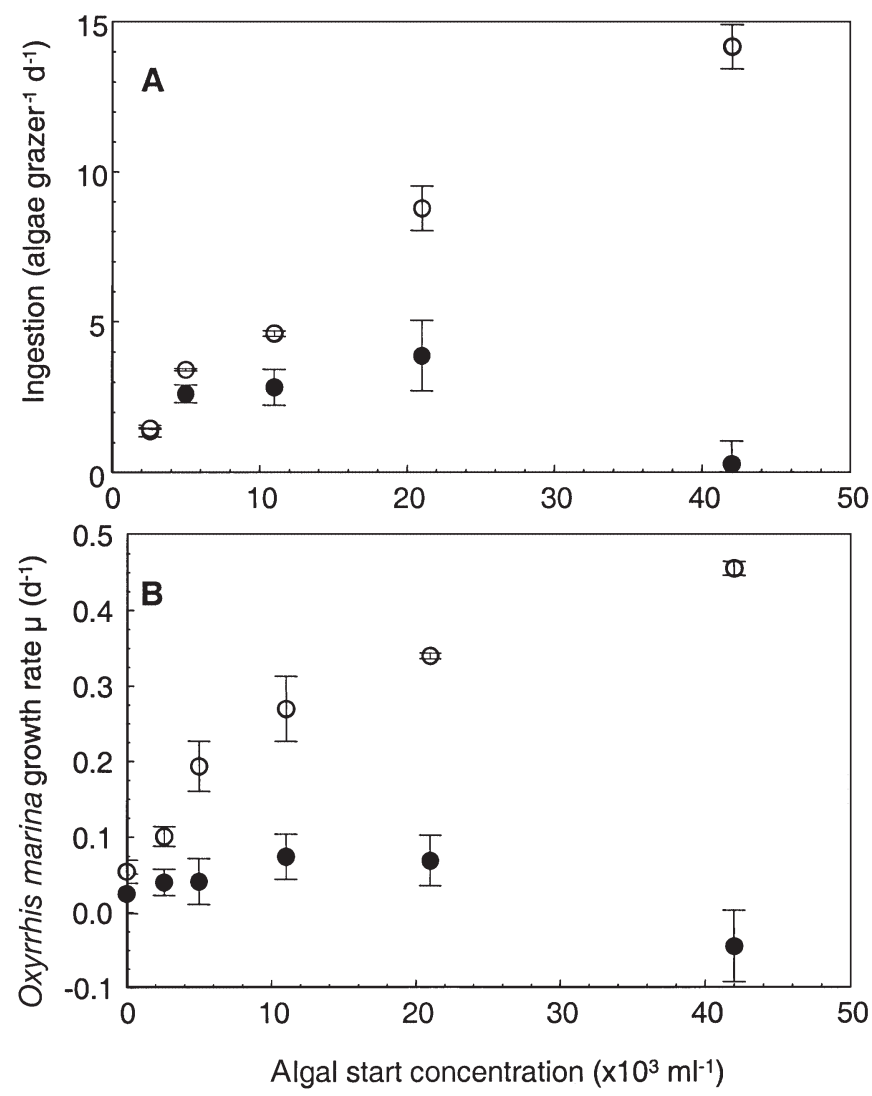

Fig. 9. Oxyrrhis marina. (A) Ingestion and (B) growth rate as a function of initial prey concentration calculated for the 0 to $2 \mathrm{~d}$ period when incubated with Prymnesium parvum (•) or Rhodomonas sp. (O). Data points represent mean values $(n=3)$ with error bars $( \pm 1$ SD) 


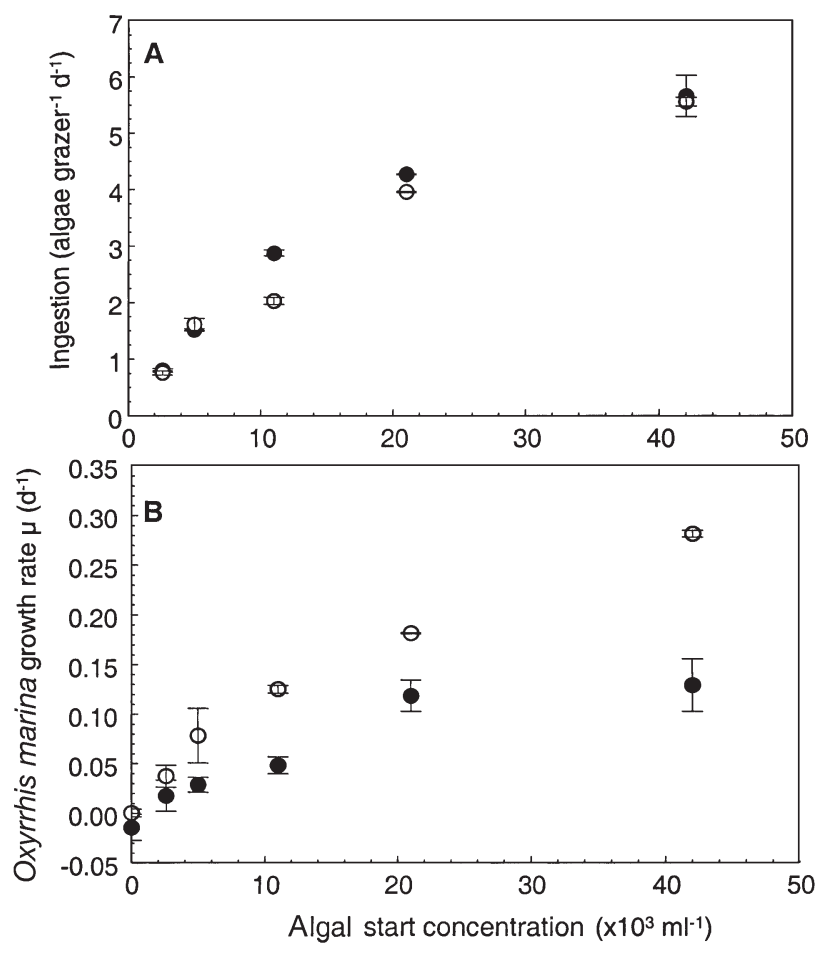

Fig. 10. Oxyrrhis marina. (A) Ingestion and (B) growth rate as a function of initial prey concentration calculated for the 0 to $6 \mathrm{~d}$ period when incubated with Prymnesium parvum (•) or Rhodomonas sp. (O). Data points represent mean values $(n=3)$ with error bars $( \pm 1$ SD)

when calculated for the 0 to $6 \mathrm{~d}$ incubation period, it is evident that $O$. marina ingestion and growth had 'recovered' after the initial lag period; ingestion and growth of $P$. parvum was almost the same as for Rhodomonas sp. over the whole range of initial algal concentrations (Fig. 10A). Positive growth rates increasing with food concentration were observed for all $P$. parvum concentrations tested, although they were lower than growth rate recorded for the corresponding Rhodomonas sp. concentrations (Fig. 10B). At the final sampling after $11 \mathrm{~d}, P$. parvum, like Rhodomonas sp., was drastically reduced in all experimental flasks, whereas cell numbers had slightly increased in the phytoplankton control cultures (Fig. 11A,B). For both algal prey, final concentrations of $O$. marina were linearly dependant on the initial algal concentration (Fig. 11C).

\section{DISCUSSION}

In the present study, toxic effects of the haptophyte Prymnesium parvum on the heterotrophic dinoflagellate Oxyrrhis marina were demonstrated. Toxicity of $P$. parvum is defined here by its lytic effects towards
O. marina. In agreement with these results, toxicity of $P$. parvum cultures used in the described semi-continuous culture experiment also has been proved by standard hemolytic tests and by its negative effects on a range of autotrophic algae (C. Legrand pers. comm.). It is well known that $P$. parvum under certain conditions produces highly potent toxins with a broad spectrum of different biological effects that are released to the water (Shilo 1967). Prymnesium's toxins are ichtyotoxic (Ulitzur \& Shilo 1966), pharmacologically active (Meldahl \& Fonnum 1993, 1995) and exert lytic effects on various cell types such as erythrocytes (Yariv \& Hestrin 1961), bacteria (Ulitzur \& Shilo 1970) and a number of nucleated cells (Shilo \& Rosenberg 1960, Dafni \& Giberman 1972). In addition, negative effects towards a range of marine organisms have been reported.
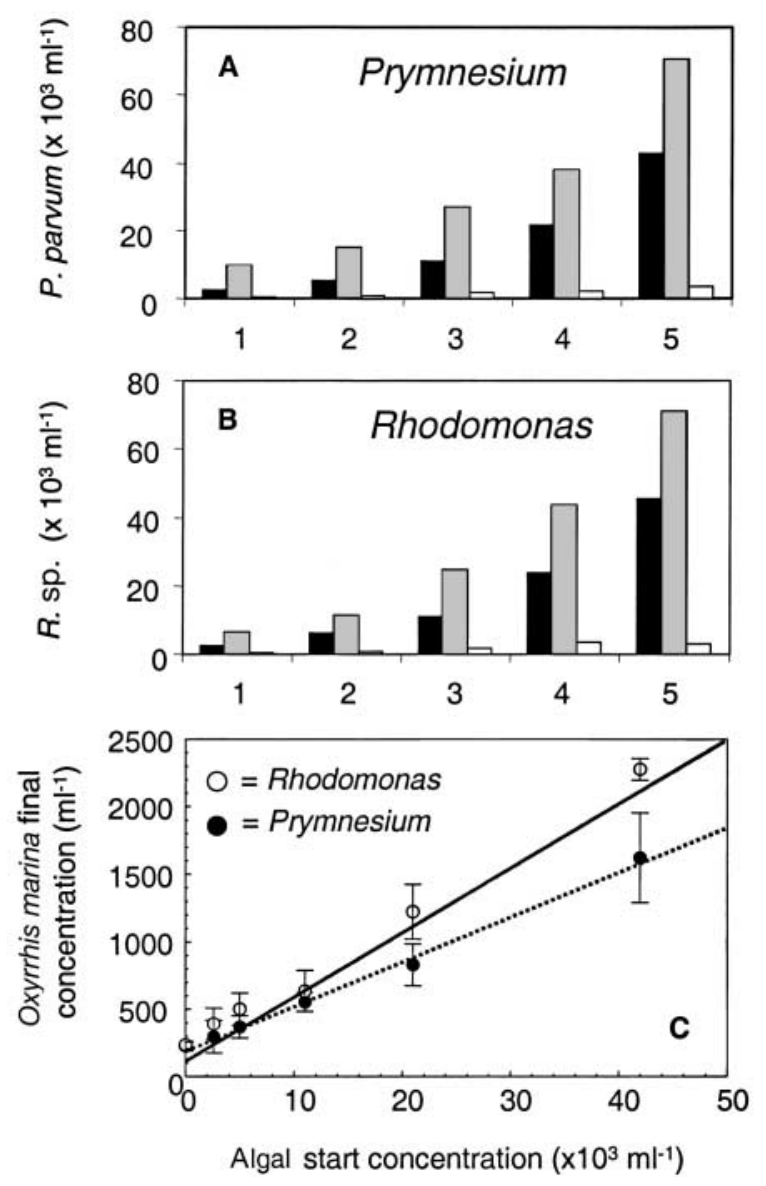

Fig. 11. Cell numbers of (A) Prymnesium parvum and (B) Rhodomonas sp. Initial concentrations (black bars) and final concentrations after $11 \mathrm{~d}$ incubation of control (grey bars) and experimental (white bars) flasks are given for the 5 different algal start concentrations ( 1 to 5 on the $x$-axis). (C) Final concentration of Oxyrrhis marina after $11 \mathrm{~d}$ as a function of initial prey concentration when fed with P. parvum $(\bullet)$ or Rhodomonas sp. (O). Data points represent mean values $(\mathrm{n}=3)$ with error bars $( \pm 1 \mathrm{SD})$ 
Valkanov (1964) briefly described the reactions of a broad range of different organisms upon exposure to $P$. parvum. Interestingly, he also tested $O$. marina and reported that all individuals died within 10 to $60 \mathrm{~min}$ after exposure to P. parvum.

Toxic effects of Prymnesium are known to be due to extracellular toxins (Shilo 1967). Accordingly, here, I showed that toxic effects towards $O$. marina were apparent when using cell free culture filtrate. However, lytic effects of cell-free filtrate occurred to a lesser degree compared to the effect of algal suspensions. This is most likely because of the known amphiphatic properties of the toxin molecules and their ability to form aggregates or micelles in solution (Ulitzur 1973). The formation of aggregates certainly affects the filterability of dissolved extracellular toxins. Using a set of filters of different pore size, Ulitzur (1973) convincingly showed that toxin micelles are typically larger than $0.6 \mu \mathrm{m}$ and about $50 \%$ of hemolysis aggregates are larger than $1 \mu \mathrm{m}$, which is roughly the pore size of the glass fibre filter used in the present study. Furthermore, it is likely that toxin aggregates, rather than the individual molecules, are responsible for the haemolytic activity of the Prymnesium toxin (Ulitzur 1973, Moran \& Hani 1974), as was also shown for the detergent sodium dodecyl sulfate (Armstrong 1957). However, neither the haemolysin nor the ichthyotoxin is solely extracellular, because both can be extracted from cells in large amounts (Shilo \& Rosenberg 1960). There are, however, no indications of any ecological impact of intracellular toxins of $P$. parvum. In fact, negative effects of $P$. parvum in situ are always the consequence of a direct exposure of target organisms to extracellular toxins. Thus, if or to what extent the initially observed (but admittedly low) ingestion of $P$. parvum by $O$. marina and, hence, the incorporation of intracellular toxins is involved in negative effects towards grazers remains unknown.

Interestingly, percentage mortality of Oxyrrhis marina was not only reduced by diluting Prymnesium parvum, but also by increasing the dinoflagellate concentration. Moreover, upon repeated additions of O. marina, mortality declined, reaching 0 after the fifth addition. Supporting observations can be extracted from older literature. Padilla (1970) showed that the time course and extent of haemolysis were dependant on the applied concentrations of rat erythrocytes. Reich \& Rotberg (1958), applying standard ichthyotoxicity tests with $P$. parvum, replaced dead fish with live ones and found profound differences in the time required to kill the fish. After the third addition, all fish remained alive and the authors suggested that the toxin is absorbed from the solution by the fish or by their heavy excretion of mucus (Reich \& Rotberg 1958). Normally, percentage mortality recorded in toxicity tests is assumed to be the result of a log-normal distribution in the sensitivity of individual target organisms to a given toxin concentration. In the case of $P$. parvum toxin, however, percentage mortality also seems to be determined by the apparent amount of toxin available per target organism, which itself is not constant but depends on the target concentration. This result underlines the need to standardise toxicity tests applied to $P$. parvum with respect to target concentration, in order to obtain reproducible and comparable results. More interesting, however, these results also clearly indicate that the toxin is removed from the system. By increasing the O. marina cell concentration, increasing amount of dissolved organic matter (DOM) were also added, and it is possible that DOM could alter toxicity. More probable, however, is that the majority of the toxin is removed from the system by its action, that is by binding to the membrane of the target organisms.

There are indications in the literature that the lysine molecules produced by Prymnesium parvum may become inert upon contact with cell surface. By using tritium-labelled toxin, Martin \& Padilla (1971) found that after only $30 \mathrm{~s}$ exposure of erythrocytes to prymnesin, $40 \%$ of the toxin was removed from the supernatant fluid, and the majority of it was firmly bound. During the whole prolytic period (100 s) the toxin was bound to the erythrocytes in linear time course and was completely removed from the system during this interval (Rauckman \& Padilla, cited in Martin \& Padilla 1971). Moreover, rates of erythrocyte haemolysis induced by $P$. parvum toxin decrease upon addition of certain lipids (cephalin, cholesterol, phosphatidylcholin) (Martin \& Padilla 1971, Igarashi et al. 1998). This effects was ascribed to a reduction in the effective concentration of prymnesin owing to the formation of a toxin-inhibitor complex (Martin \& Padilla 1971). This suggests that prymnesin may react primarily with membrane sterols. Indeed, using liposomes as a model membrane system, Imai \& Inoue (1974) showed that prymnesin caused severe damage to liposomes containing cholesterol but did not affect those without cholesterol. However, additional specific binding sites may exist, as Ulitzur \& Shilo (1970) showed that prymnesin lysed spheroplasts or protoplasts of some bacteria whose membranes contain no cholesterol.

To conclude, toxicity of Prymnesium parvum in natural systems may be highly influenced by total biomass of co-occurring species and perhaps by concentrations of non-living particulate organic matter (POM) and DOM.

Nothing is known about long-term stability of such toxin/binding-sites complexes. In the experiment with successive addition of Oxyrrhis marina, lysis induced mortality reached 0 after $5 \mathrm{~h}$ of incubation, indicating 
that toxin/binding-site complexes are stable at least in the magnitude of hours. If the Prymnesium parvum toxins are permanently removed from the system, addition of highly specific artificial binding sites to $P$. parvum blooms may represent a promising tool to detoxify bloom waters.

In the $-\mathrm{P}$ continuous culture experiment, $\mathrm{P}$ was the limiting nutrient as indicated by high particulate $\mathrm{C} / \mathrm{P}$ ratios measured at the end of the experiment by Skovgaard et al. (2003). Under these conditions tested in the semi-continuous culture experiment, short-term toxic effects (cell lysis) prevent significant grazing of Oxyrrhis marina on Prymnesium parvum. This finding, however, does not necessarily lead to the conclusion that toxins are used to eliminate a potential predator, as $P$. parvum even lacking toxicity might be a poor prey for O. marina for reasons other than toxicity, e.g. size, handling problems or nutritional composition. It therefore was shown that, under certain conditions, O. marina is indeed a potential predator able to graze and grow on $P$. parvum with rates comparable to the nontoxic control species Rhodomonas sp. As nutrient replete semi-continuous cultures of $P$. parvum $\left(100 \times 10^{3}\right.$ cells $\mathrm{ml}^{-1}$ ) grown under the same conditions as used for the P-limited cultures also caused cell lysis of $O$. marina (own unpubl. results), a different experimental set-up was chosen in order to minimise toxin production/accumulation. After batch culture growth of $P$. parvum in nutrient-replete medium without bubbling at relatively low light intensities, the incubation condition in particular constitutes of lower cell concentration $\left(<50 \times 10^{3}\right.$ $\mathrm{ml}^{-1}$ ) and dim light. A nutrient replete medium was chosen as there are several reports that toxicity of both $P$. parvum and $P$. patelliferum is enhanced by nutrient limitation (Shilo 1971, Dafni et al. 1972, Larsen et al. 1993, Meldahl et al. 1994, Johansson \& Granéli 1999, Johansson 2000, Legrand et al. 2001). Bubbling was omitted because aeration of cultures was shown to be important in promoting intracellular toxin production (Igarashi et al. 1995). The importance of light conditions is more difficult to evaluate since light obviously has 2 different roles working in opposite directions. Light has been claimed to be essential for toxin production (Padan et al. 1967, Shilo 1967) with higher light conditions augmenting toxin production (Shilo \& Aschner 1953). On the other hand, the extracellular toxins are known to be rapidly inactivated by exposure to visible and ultraviolet light (Parnas et al. 1962, Reich \& Parnas 1962). This set of conditions is not meant to be exclusive; there may be other conditions that could also reduce toxic effects and allow $O$. marina to ingest $P$. parvum and grow in its presence (e.g. high concentrations of POM and DOM; see above). In any case, under the chosen conditions, negative effects (low ingestion, negative growth rate) were only apparent at the beginning of the experiment at higher P. parvum concentrations. The obvious disappearance of these negative effects with time, i.e. high ingestion and growth when calculated for the 0 to $6 \mathrm{~d}$ period, might be due to acclimatisation of $O$. marina towards low amounts of toxin. More likely, however, is the possibility that a certain, albeit low, amount of extracellular toxin was present at the beginning, being introduced by inoculating $P$. parvum from the light grown culture. This initial stock of extracellular toxin then disappeared with time due to adsorption and/or degradation. Little is known about negative effects of Prymnesium toxins at lower, sublethal concentrations. For the closely related genus Chrysochromulina, Estep \& MacIntyre (1989) proposed the concept of dasmotrophy, a theory of auxotrophy following induced osmosis. They speculated that extracellular toxins produced by Chrysochromulina simply punch holes in the cell membrane of other organisms, producing a transient nutrient leakage benefiting Chrysochromulina. John et al. (2002) recently showed that Oxyrrhis marina was not killed by the presence or by the ingestion of toxic Chrysochromulina polylepis, but that profound differences in ingestion and growth of $O$. marina when fed a toxic or a non-toxic clone of C. polylepis were apparent, indicating that the toxin deters grazers. The same may hold true for $P$. parvum toxins for a certain range of sublethal concentrations, as indicated by the initially low ingestion and growth of $O$. marina in the batch culture experiment.

In conclusion, Prymnesium parvum is a suitable prey for Oxyrrhis marina sustaining growth if toxicity is low. This indicates that protozoan grazing might be an important factor controlling $P$. parvum population dynamics prior to bloom build-up when environmental conditions prevent larger amounts of extracellular toxin to be produced and/or to accumulate in the water. However, when sufficient amounts of toxins are produced and released to the medium, they may act as a chemical defence against grazers. This may especially be the case for nutrient-limited bloom conditions, as nutrient stress is supposed to enhance toxin production (Shilo 1971, Johansson \& Granéli 1999). P. parvum cell concentrations causing cell lysis of $O$. marina are well below reported bloom concentrations of $P$. parvum of up to $10^{6}$ cells $\mathrm{ml}^{-1}$ (reviewed by Edvardsen $\&$ Paasche 1998). Hence, elimination of grazers may be an important mechanism in the development and maintenance of dense blooms of this species in nature.

Prymnesium not only benefits from toxin production by not being grazed. The results clearly showed that there is an almost quantitative relationship between immobilisation/lysis of Oxyrrhis marina and the appearance of aggregates and phagotrophy. In addition to the known uptake of bacteria by Prymnesium (Nygaard \& Tobiesen 1993, Legrand et al. 2001), the impressive 
phagotrophic capacity of Prymnesium ingesting prey of different size, sometimes even larger than itself, was recently reported (Tillmann 1998). Microscopic observation supports the notion that Prymnesium intrinsically is a rather poor hunter: it is a poor swimmer and the stiff haptonema, which is poorly adapted to catching particles (in contrast to Chrysochromulina, see Kawachi et al. 1991), is not involved in the feeding process (Tillmann 1998). Food uptake by means of pseudopodia formed at the posterior part of the cell is rather slow and takes minutes (Tillmann 1998). Thus, Prymnesium seems to be unable to catch and ingest motile prey. Recently, it was convincingly shown that Prymnesium exotoxins are indeed used to immobilise and kill potential prey organisms prior to ingestion (Skovgaard \& Hansen 2003). However, it still remains unknown whether or to what extent phagotrophy may lead to an increased growth rate of Prymnesium.

To conclude, toxicity of Prymnesium parvum, although its controlling factors are still insufficiently understood, is a key factor in determining the interaction with protozoan grazers. If toxicity is low, $P$. parvum is a suitable prey for Oxyrrhis marina. At high toxicity levels, however, $O$. marina is rapidly killed and ingested by $P$. parvum; thus, reversing the normal direction of grazing interactions between protozoa and algae.

Acknowledgements. Special thanks are due to Alf Skovgaard and Per-Juel Hansen for setting up the semi-continuous cultures and for the opportunity to work at the Marine Laboratory, Helsingoer. I also thank Cathrine Legrand, Per-Juel Hansen and Alf Skovgaard for valuable discussions, Victor Smetacek and 3 anonymous reviewers for comments and suggestions on the manuscript, and Steve Pueppke for correcting the English. This work was supported by the European Commission (Research Directorate General-Environment Programme-Marine Ecosystems) through the BIOHAB project 'Biological control of Harmful Algal Blooms in European coastal waters: role of eutrophication' (contract EVK3-CT9900015). The BIOHAB project is part of the EC EUROHAB cluster.

\section{LITERATURE CITED}

Armstrong WM (1957) Enhancement of the biological activity of sodium dodecyl sulphate by inorganic cations. Nature 179:780-781

Dafni Z, Giberman E (1972) Nature of initial damage to Ehrlich ascites cells caused by Prymnesium parvum toxin. Biochim Biophys Acta 255:380-385

Dafni Z, Ulitzur S, Shilo M (1972) Influence of light and phosphate on toxin production and growth of Prymnesium parvum. J Gen Microbiol 70:199-207

Edvardsen B, Paasche E (1998) Bloom dynamics and physiology of Prymnesium and Chrysochromulina. In: Anderson DM, Cembella AD, Hallegraeff GM (eds) Physiological ecology of harmful algae blooms. Springer Verlag, Berlin, p 193-208
Estep KW, MacIntyre F (1989) Taxonomy, life cycle, distribution and dasmotrophy of Chrysochromulina: a theory accounting for scales, haptonema, muciferous bodies and toxicity. Mar Ecol Prog Ser 57:11-21

Fiedler PC (1982) Zooplankton avoidance and reduced grazing responses to Gymnodinium splendens (Dinophyceae). Limnol Oceanogr 27:961-965

Frost BW (1972) Effects of size and concentration of food particles on the feeding behavior of the marine planktonic copepod Calanus pacificus. Limnol Oceanogr 17:805-815

Green JC, Hibberd DJ, Pienaar RN (1982) The taxonomy of Prymnesium (Prymnesiophyceae) including a description on a new cosmopolitan species, P. patellifera sp. nov., and further observations on P. parvum N. Carter. Br Phycol J 17:363-382

Guillard RRL, Ryther JH (1962) Studies on marine planktonic diatoms. I. Cyclotella nana Hustedt and Detonula confervaceae (Cleve) Gran. Can J Microbiol 8:229-239

Heinbokel JF (1978) Studies on the functional role of tintinnids in the southern California Bight. I. Grazing and growth rates in laboratory cultures. Mar Biol 47:177-189

Hewlett PS, Placklet RL (1979) The probit and similar transformation. In: Hewlett PS, Placklet RL (eds) An introduction to the interpretation of quantal response in biology. Edward Arnold Ltd., London, p 12-17

Holdway PA, Watson RA, Moss B (1978) Aspects of the ecology of Prymnesium parvum and water chemistry in the Nordfolk Broads, England. Freshw Biol 8:295-311

Igarashi T, Oshima Y, Murata M, Yasumoto T (1995) Chemical studies on prymnesins isolated from Prymnesium parvum. In: Lassus P, Arzul G, Erard E, Gentien P, Marcaillou C (eds) Harmful marine algal blooms. Lavoisier, Intercept, London, p 303-308

Igarashi T, Satake M, Yasumoto T (1996) Prymnesin-2: a potent ichtyotoxic and hemolytic glycoside isolated from the red tide alga Prymnesium parvum. J Am Chem Soc 118:479-480

Igarashi T, Aritake S, Yasumoto T (1998) Biological activities of Prymnesin-2 isolated from a red tide alga Prymnesium parvum. Nat Toxins 6:35-41

Imai M, Inoue K (1974) The mechanism of the action of prymnesium toxin on membranes. Biochim Biophys Acta 352 $344-348$

Johansson N (2000) Ecological implications of the production of toxic substances by fish killing phytoplankton species grown under variable N:P-ratios. PhD thesis, Lund University, Sweden

Johansson N, Granéli E (1999) Influence of different nutrient conditions on cell density, chemical composition and toxicity of Prymnesium parvum (Haptophyta) in semi-continuous cultures. J Exp Mar Biol Ecol 239:243-258

John U, Tillmann U, Medlin L (2002) A comparative approach to study inhibition of grazing and lipid composition of a toxic and non-toxic clone of Chrysochromulina polylepis (Prymnesiophyceae). Harmful Algae 1:45-57

Kaartvedt S, Johnsen TM, Aksnes DL, Lie U, Svendsen HS (1991) Occurence of the toxic phytoflagellate Prymnesium parvum and associated fish mortality in a norwegian fjord system. Can J Fish Aquat Sci 48:2316-2323

Kawachi M, Inouye I, Maeda O, Chihara M (1991) The haptonema as a food-capturing device: observations on Chrysochromulina hirta (Prymnesiophyceae). Phycologia 30:563-573

Larsen A (1999) Prymnesium parvum and P. patelliferum (Haptophyta) - one species. Phycologia 38:541-543

Larsen A, Medlin LK (1997) Inter- and intraspecific genetic variation in twelve Prymnesium (Haptophyceae) clones. 
J Phycol 33:1007-1015

Larsen A, Eikrem W, Paasche E (1993) Growth and toxicity in Prymnesium patelliferum (Prymnesiophyceae) isolated from Norwegian waters. Can J Bot 71:1357-1362

Legrand C, Johansson N, Johnsen G, Borsheim KY, Granéli E (2001) Phagotrophy and toxicity variation in the mixotrophic Prymnesium patelliferum (Haptophyceae). Limnol Oceanogr 46:1208-1214

Martin DF, Padilla GM (1971) Hemolysis induced by Prymnesium parvum toxin. Kinetics and binding. Biochim Biophys Acta 241:213-225

Meldahl AS, Fonnum F (1993) The effect of toxins of Prymnesium patelliferum on neuritransmitter transport mechanisms. The development of a sensitive test method. J Toxicol Environ Health 38:57-67

Meldahl AS, Fonnum F (1995) The effects of a purified toxic extract of Prymnesium patelliferum on transport of ions through the plasma membrane of synaptosomes. Toxicon 33:1071-1086

Meldahl AS, Edvardsen B, Fonnum F (1994) Toxicity of 4 potentially ichthyotoxic marine phytoflagellates determined by 4 different test methods. J Toxicol Environ Health 42:289-301

Moestrup O (1994) Economic aspects: 'blooms', nuisance species, and toxins. In: Green JC, Leadbeater BSC (eds) The haptophyte algae. Clarendon Press, Oxford, p 265-285

Moran A, Hani A (1974) The effect of prymnesin on the electric conductivity of thin lipid membranes. J Membr Biol 16: $237-256$

Nejstgaard JC, Solberg PT (1996) Repression of copepod feeding and fecundity by the toxic haptophyte Prymnesium patelliferum. Sarsia 81:329-338

Nejstgaard JC, Bamstedt U, Bagoien E, Solberg PT (1995) Algal constrains on copepod grazing. Growth state, toxicity, cell size, and season as regulating factors. ICES J Mar Sci 52:347-357

Nygaard K, Tobiesen A (1993) Bacterivory in algae: a survival strategy during nutrient limitation. Limnol Oceanogr 38: 273-279

Padan E, Ginzburg D, Shilo M (1967) Growth and colony formation of the phytoflagellate Prymnesium parvum Carter on solid media. J Protozool 14:477-480

Padilla GM (1970) Growth and toxigenesis of the chrysomonad Prymnesium parvum as a function of salinity. J Protozool 17:456-462

Parnas I, Reich K, Bergmann F (1962) Photoinactivation of ichtyotoxin from axenic cultures of Prymnesium parvum. Applied Microbiology 10:237-239

Petrova VJ (1966) Verbreitung und massenhafte Entwicklung der giftigen Chrysomonade Prymnesium parvum Carter in den Seen an der bulgarischen Schwarzmeerküste. Z Fisch Hilfswiss 14:9-14 (with English summary)

Editorial responsibility: John Dolan, Villefranche-sur-Mer, France
Reich K, Aschner M (1947) Mass develpment and control of the phytoflagellate Prymnesium parvum in fish ponds in palestine. Palest J Bot 4:14-23

Reich K, Parnas I (1962) Effect of illumination on ichtyotoxin in an axenic culture of Prymnesium parvum Carter. J Protozool 9:38-40

Reich K, Rotberg M (1958) Some factors influencing the formation of toxin poisonous to fish in bacteria-free cultures of Prymnesium. Bull Res Counc Isr 78:199-202

Shilo M (1967) Formation and mode of action of algal toxins. Bacteriol Rev 31:180-193

Shilo M (1971) Toxins of Chrysophyceae. In: Kadis S, Ciegler A, Ajl SJ (eds) Microbial toxins. Algal and fungal toxins. Academic Press, New York, p 67-103

Shilo M (1981) The toxic principle of Prymnesium parvum. In: Carmichael WW (ed) The water environment. Algal toxins and health. Plenum Press, New York, p 33-47

Shilo M, Aschner M (1953) Factors govering the toxicity of cultures containing the phytoflagellate Prymnesium parvum Carter. J Gen Microbiol 8:333-343

Shilo M, Rosenberg RF (1960) Studies on the toxic priciples formed by the chrysomonad Prymnesium parvum Carter. Ann NY Acad Sci 90:866-876

Skovgaard A, Hansen PJ (2003) Food uptake in the harmful alga Prymnesium parvum mediated by excreted toxins. Limnol Oceanogr 48(3):1161-1166

Skovgaard A, Legrand C, Hansen PJ, Granéli E (2003) Effects of nutrient limitation on food uptake in the toxic Haptophyte Prymnesium parvum. Aquat Microb Ecol 31: 259-265

Smayda TJ (1997) Harmful algal blooms: their ecophysiology and general relevance to phytoplankton blooms in the sea. Limnol Oceanogr 42:1137-1153

Tillmann U (1998) Phagotrophy of a plastidic haptophyte, Prymnesium patelliferum. Aquat Microb Ecol 14:155-160

Tillmann U, John U (2002) Toxic effects of Alexandrium spp. on heterotrophic dinoflagellates: an allelochemical defence mechanism independent of PSP toxins. Mar Ecol Prog Ser 230:47-58

Ulitzur S (1973) The amphiphatic nature of Prymnesium parvum hemolysin. Biochim Biophys Acta 298:673-679

Ulitzur S, Shilo M (1966) Mode of action of Prymnesium parvum ichtyotoxin. J Protozool 13:332-336

Ulitzur S, Shilo M (1970) Effect of Prymnesium parvum toxin, cetyltrimethylammonium bromide and sodium dodecyl sulphate on bacteria. J Gen Microbiol 62:363-370

Valkanov A (1964) Untersuchungen über Prymnesium parvum Carter und seine toxische Einwirkung auf die Wasserorganismen. Kiel Meeresforsch 20:65-81

Yariv J, Hestrin S (1961) Toxicity of the extracellular phase of Prymnesium parvum cultures. J Gen Microbiol 24: 165-175

Submitted: November 25, 2002; Accepted: February 3, 2003 Proofs received from author(s): May 6, 2003 